\title{
Penerapan Model Discovery Learning Dengan Multimedia dalam Peningkatan Pembelajaran IPS tentang Aktivitas Ekonomi pada Siswa Kelas IV SD Negeri 1 Mergosono Tahun Ajaran 2017/2018
}

\section{Tiyar Okti Indriati ${ }^{1}$, Tri Saptuti Susiani ${ }^{2}$, Imam Suyanto ${ }^{3}$}

1,2,3 Universitas Sebelas Maret

tiyarokti@gmail.com

\section{Article History}

accepted 01/02/2019

approved 01/03/2019

published 01/04/2019

\begin{abstract}
The objectives of this research is to improve the learning of social science learning through the implementation of the Discovery Learning model using multimedia. This study is a collaborative class action research conducted in three cycles, in one and two cycles consisting of two meetings, and the third cycle consists of one meeting. The subjects of this research are the fourth grades students of SD Negeri 1 Mergosono, with the number of students 21. The results showed that the application of Discovery Learning model using multimedia can improve the social science learning about economic activity in fourth grade students of SD Negeri 1 Mergosono the academic year 2017/2018.
\end{abstract}

Keywords: Discovery Learning, Multimedia, Social Science Learning

\begin{abstract}
Abstrak
Tujuan penelitian ini untuk meningkatkan pembelajaran IPS tetang aktivitas ekonomi melalui penerapan model Discovery Learning dengan multiemdia. Penelitian ini merupakan penelitian tindakan kelas kolaboratif yang dilaksanakan dalam tiga siklus, pada siklus satu dan dua terdiri dari dua pertemuan, dan siklus tiga terdiri dari satu pertemuan. Setiap pertemuan terdiri atas tahap perencanaan, pelaksanaan, pengamatan, dan refleksi. Subjek penelitian ini adalah siswa kelas IV SD Negeri 1 Mergosono, dengan jumlah siswa 21. Hasil penelitian menunjukkan bahwa penerapan model Discovery Learning dengan multimedia dapat meningkatkan pembelajaran IPS tentang aktivitas ekonomi pada siswa kelas IV SD Negeri 1 Mergosono tahun ajaran 2017/2018.
\end{abstract}

Kata Kunci: Discovery Learning, Multimedia, Pembelajaran IPS 


\section{PENDAHULUAN}

Pendidikan merupakan kebutuhan mutlak yang harus dipenuhi sepanjang kehidupan manusia. Di dalam Undang-undang No. 20 Tahun 2003 tentang Sistem Pendidikan Nasional disebutkan bahwa pendidikan adalah usaha sadar dan terencana untuk mewujudkan suasana belajar dan proses pembelajaran agar peserta didik secara aktif mengembangkan potensi dirinya untuk memiliki kekuatan spiritual keagamaan, pengendalian diri, kepribadian, kecerdasan, akhlak mulia serta keterampilan yang diperlukan dirinya, masyarakat, bangsa, dan Negara (Depdiknas, 2003).

Jenjang pendidikan Sekolah Dasar (SD) merupakan tingkat pendidikan formal yang paling dasar. Pendidikan di tingkat SD diselenggarakan selama enam tahun bagi siswa usia 7-12 tahun. Siswa SD cenderung memiliki imajinasi dan rasa ingin tahu yang tinggi, hal tersebut merupakan modal utama untuk tumbuh dan berkembang. Ada banyak mata pelajaran yang diajarkan di SD, salah satunya yaitu IImu Pengetahuan Sosial (IPS).

IPS merupakan salah satu mata pelajaran yang mengkaji seperangkat peristiwa, fakta, konsep, dan generalisasi yang berkaitan dengan isu sosial pada tingkat SD. Melalui pendidikan IPS, diharapkan para siswa dapat diarahkan untuk menjadi warga negara Indonesia yang demokratis, dan bertanggung jawab, serta menjadi warga dunia yang cinta damai (Sapriya, 2014: 194). Dengan demikian pembelajaran IPS memerlukan penyempurnaan pembelajaran yang dilakukan oleh guru. Penyempurnaan pembelajaran ini dapat dilaksanakan melalui pemilihan pendekatan, model, metode maupun media yang tepat dalam menyampaikan setiap materi.

Tujuan pembelajaran IPS di tingkat SD yaitu: (1) mengenal konsep tentang kehidupan bermasyarakat; (2) memiliki kemampuan dasar untuk berpikir logis dan kritis, rasa ingin tahu, inkuiri, memecahkan masalah, dan keterampilan dalam kehidupan sosial; (3) memiliki komitmen dan kesadaran tentang nilai sosial dan kemanusiaan; (4) berkemampuan dalam komunikasi, bekerja sama dan dalam masyarakat baik tingkat lokal, nasional maupun global. (Sapriya, 2014: 194).

Agar tujuan pembelajaran IPS dapat tercapai dengan maksimal, hendaknya pembelajaran bersifat mendidik, menyenangkan, menarik, serta membangkitkan aktivitas dan kreativitas anak, sehingga siswa tidak mudah jenuh dan bosan. Cara yang dapat dilakukan guru untuk mengantisipasi kejenuhan dan kebosanan pada siswa yaitu dengan menciptakan kondisi belajar yang menghasilkan tujuan pembelajaran yang berkualitas dan berbobot. Untuk menciptakan kondisi belajar yang demikian maka perlu adanya pemilihan model dan metode pembelajaran yang tepat. Menurut Susanto (2014: 3) selain penggunaan model yang tepat perlu adanya penggunaan media yang tepat pula untuk menarik perhatian siswa. Media pembelajaran yang indah, menarik dan interaktif merupakan sarana agar peserta didik tidak jenuh dalam mengikuti pelajaran dan memberikan efek besar pada siswa agar termotivasi dan mempermudah dalam menerima materi pelajaran. Dengan demikian, tugas penting bagi seorang guru demi mencapai tujuan pembelajaran IPS adalah memilih model, pendekatan, metode, maupun media pembelajaran yang sesuai.

Hasil ulangan tengah semeser satu mata pelajaran IPS kelas IV SD Negeri 1 Mergosono dapat dikatakan belum berhasil. Hasil UTS tersebut menunjukkan bahwa dari jumlah 21 siswa ada sebanyak $33 \%$ atau 7 siswa yang sudah mencapai KKM serta $67 \%$ atau 14 siswa belum mencapai KKM, dengan nilai rata-rata yaitu 67. KKM yang ditetapkan adalah 70 . Hal tersebut dikarenakan pada pelaksanaan pembelajaran guru masih terlalu dominan. . Dalam menyampaikan materi, guru sangat terpaku pada buku 
sumber dan belum menggunakan media pembelajaran sehingga kurang menarik perhatian siswa. Hal itu terlihat dengan masih adanya siswa yang bermain sendiri, tidak memperhatikan guru, dan terlihat bosan. Hal tersebut terjadi karena selama proses pembelajaran, siswa hanya menerima apa yang guru berikan tanpa adanya usaha atau kesempatan untuk menemukan sendiri konsep pembelajaran tersebut.

Berdasarkan kondisi tersebut peneliti bersama guru memutuskan untuk memperbaiki pembelajaran IPS tersebut dengan menerapkan model discovery learning dengan multimedia.

Model discovery learning merupakan salah satu model pembelajaran yang berpusat pada siswa dan membantu siswa dalam membentuk konsep. Model discovery learning lebih banyak melibatkan siswa dalam proses pembelajaran. Pembelajaran discovery learning adalah suatu pembelajaran untuk mengembangkan cara belajar siswa aktif dengan menemukan sendiri, menyelidiki sendiri, maka hasil yang diperoleh siswa akan setia dan tahan lama dalam ingatan, tidak akan mudah dilupakan oleh siswa (Hosnan, 2014 : 282).

Model pembelajaran discovery learning akan lebih maksimal hasilnya apabila didukung oleh media yang variatif seperti multimedia. Menurut Munadi (2013: 148) multimedia adalah media pembelajaran yang mampu melibatkan banyak indera dan organ tubuh selama proses pembelajaran berlangsung. Multimedia membuat proses pembelajaran lebih menarik, interaktif, kualitas belajar dapat ditingkatkan, pembelajaran dapat dilakukan di mana saja dan kapan saja, dan sikap belajar siswa dapat ditingkatkan. Melalui penggunaan multimedia sebagai media pembelajaran maka diharapkan siswa dapat dengan mudah memahami dan menerima materi yang dipelajari sehingga hasil belajar siswa meningkat.

Berdasrkan uraian yang telah dikemukakan, maka rumusan masalah dalam penelitian ini yaitu 1) bagaimana penerapan model discovery learning dengan multimedia? 2) apakah penerapan model discovery learning dengan multimedia dapat meningkatkan pembelajaran IPS tetang aktivitas ekonomi pada siswa kelas IV SD Negeri 1 Mergosono tahun ajaran 2017/2018 ? 3) apakah kendala dan solusi yang ditemukan dalam penerapan model discovery learning dengan multimedia dalam peningkatan pembelajaran IPS tentang aktivitas ekonomi pada siswa kelas IV ?

Tujuan penelitian ini yaitu untuk 1) mendeskripsikan langkah-langkah penerapan model discovery learning dengan multimedia? 2) meningkatkan pembelajaran IPS tentang aktivitas ekonomi melalui penerapan discovery learning dengan multimedia pada siswa kelas IV SD Negeri 1 Mergosono tahun ajaran 2017/2018, dan 3) mendeskripsikan kendala dan solusi dalam penerapan model discovery learning dengan multimedia dalam peningkatan pembelajaran IPS tentang aktivitas ekonomi pada siswa kelas IV

\section{METODE}

Penelitian tindakan kelas ini dilakukan secara kolaboratif. Penelitian dilakukan di SD Negeri 1 Mergosono dengan subjek penelitian siswa kelas IV yang berjumlah 21 siswa. Penelitian ini menggunakan data kualitatif dan data kuantitatif.

Teknik pengumpulan data yang digunakan yaitu teknik tes dan non tes. Teknik tes digunakan untuk mengukur pemahaman siswa terhadap pembelajaran yang dilakukan. Teknik non tes yang digunakan adalah observasi dan wawancara. Alat pengumpulan data berupa lembar observasi dan wawancara terhadap guru dan siswa.

Uji validitas data yang digunakan yaitu triangulasi sumber dan triangulasi teknik. Analisis data berupa data kualitatif dan data kuantitatif yang dianalisis melalui teknik reduksi data, penyajian data dan penyimpulan. 
Indikator pencapaian yang ditargetkan pada penelitian ini yaitu $85 \%$ pada masing-masing indikator, serta KKM yang ditetapkan yaitu 70 . Penelitian ini dilakukan selama tiga siklus degan lima kali pertemuan. Pertemuan pertama dan kedua sebanyak dua kali pertemuan dan siklus tiga hanya satu kali pertemuan. Pelaksanaan setiap pertemuan meliputi empat tahapan, yaitu: (1) perencanaan; (2) pelaksanaan; (3) pengamatan; dan (4) refleksi. (Arikunto, 2013: 131).

\section{HASIL DAN PEMBAHASAN}

Penerapan model discovery learning dengan multimedia dilaksanakan dengan langkah sebagai berikut: (1) stimulation dnegan multimedia; (2) problem statement dengan multiemdia; (3) data collecting dengan multiemdia; (4) data processing; (5) verification; dan (6) generalization.

Data hasil observasi penerapan model discovery learning dengan multimedia terhadap guru dan siswa sebagai berikut:

Tabel. 1. Hasil Observasi terhadap guru dan siswa pada Siklus I,II, dan III

\begin{tabular}{ccc}
\hline Siklus & Guru (\%) & $\begin{array}{c}\text { Siswa } \\
(\%)\end{array}$ \\
\hline I & 70,5 & 66,5 \\
II & 88,5 & 86,5 \\
III & 95 & 89 \\
\hline
\end{tabular}

Berdasarkan data pada tabel 1. di atas, dapat diketahui bahwa proses pembelajaran di siklus I, II, dan III selalu mengalami peningkatan. Pada siklus I, guru mencapai 70,5\%; siklus II meningkat menjadi $88,5 \%$; dan pada siklus III meningkat menjadi 95\%. Sedangkan siswa pada siklus I mencapai $66,5 \%$, siklus II $86,5 \%$, dan pada siklus III $89 \%$.

Selain proses pembelajaran yang dilaksanakan guru dan siswa dengan menerapkan Discovery Learning dengan Multimedia, penelitian ini juga mengambil data nilai hasil belajar IPS. Perbandingan hasil belajar siswa pada siklus I, II, dan III dapa dilihat pada tabel berikut.

Tabel 4.2 Perbandingan Nilai Hasil Belajar Siswa pada Siklus I, II, dan III

\begin{tabular}{lccc}
\hline \multirow{2}{*}{ Tindakan } & \multicolumn{3}{c}{ Siklus } \\
\cline { 2 - 4 } & I & II & III \\
\hline Rata-rata & 72,3 & 85,1 & 90 \\
Nilai & & & \\
Tuntas (\%) & 52,35 & 78,6 & 90 \\
Tidak & 47,65 & 21,4 & 10 \\
Tuntas (\%) & & & \\
\hline
\end{tabular}

Berdasarkan tabel di atas dapat diketahui bahwa ketuntasan hasil belajar siswa mengalami peningkafan pada tiap siklusnya. Pada siklus I nilai rata-rata yang diperoleh adalah 72,3 dengan persentase ketuntasan $52,35 \%$. Siklus II, nilai rata-ratanya adalah 85,1 meningkat dari rata-rata sebelumnya, dan persentasenya juga meningkat menjadi $78,6 \%$. Pada siklus III, nilai rata-ratanya menjadi 90 , dan persentase ketuntasannya meningkat menjadi $90,48 \%$. 
Hasil penelitian ini relevan dengan penelitian yang dilakukan oleh Kuswati (2014) yang mengungkapkan bahwa penerapan model discovery learning dapat meningkatkan pembelajaran IPA. Penelitian lainnya yaitu oleh In'am dan Hajar (2017: 66) yang menyatakan bahwa dengan menerapkan model discovery learning dapat meningkatkan aktivitas siswa pada pembelajaran sehingga semakin baik.

\section{SIMPULAN}

Berdasarkan analisis hasil penelitian dan pembahasan mengenai penerapan model discovery learning dengan multimedia dalam peningkatan pembelajaran IPS pada siswa kelas IV SD Negeri 1 Mergosono tahun ajaran 2017/2018, diperoleh simpulan sebagai berikut: (1) penerapan model pembelajaran discovery learning dengan multimedia dalam peningkatan pembelajaran IPS pada siswa kelas IV SD Negeri 1 Mergosono tahun ajaran 2017/2018 dilaksanakan dengan langkah-langkah: (a) stimulation dengan multimedia; (b) problem statement dengan multimedia; (c) data collecting dengan multimedia; (d) data processing; (e) verification; dan (f) generalization; (2) penerapan model discovery learning dengan multimedia dapat meningkatkan pembelajaran IPS tentang aktivitas ekonomi pada siswa kelas IV SD Negeri 1 Mergosono tahun ajaran 2017/2018. Hal tersebut dibuktikan dengan adanya peningkatan hasil belajar pada tiap siklusnya. Pada siklus I yaitu 52,35\%, siklus II meningkat menjadi $78,6 \%$, dan pada siklus III persentase ketuntasan mencapai $90 \%$; (3) endala pada penerapan model discovery learning dengan multimedia dalam peningkatan pembelajaran IPS tentang aktivitas ekonomi pada siswa kelas IV SD Negeri 1 Mergosono tahun ajaran 2017/2018 yaitu (a) siswa belum memberikan tanggapan saat presentasi kelompok lain; dan (b) siswa belum berani menjawab pertanyaan teman karena takut salah. Adapun solusinya yaitu (a) siswa dibimbing untuk memberikan tanggapan; dan (b) siswa diberi motivasi untuk berani menjawab pertanyaan teman tanpa takut salah.

Berdasarkan simpulan di atas, peneliti mengajukan beberapa saran yaitu: (1) bagi siswa, siswa lebih aktif dalam setiap kegiatan pembelajaran yang dilakukan dan jangan malu untuk bertanya apabila belum jelas; (2) bagi guru, membimbing siswa untuk aktif dalam berdiskusi serta memberikan tanggapan; (3) bagi sekolah, memfasilitasi guru untuk menggali potensi dalam penerapan model discovery learning dengan multimedia, dan merekomendasikan kepada guru-guru lain dalam menerapkan model pembelajaran discovery learning dengan multimedia; dan (4) bagi peneliti, Hasil penelitian ini dapat dijadikan sebagai dasar dan referensi dalam mengembangkan penelitian dengan menerapkan model discovery learning dengan multimedia. 


\section{DAFTAR PUSTAKA}

Arikunto, S. (2013). Prosedur Penelitian Suatu Pendekatan Praktik. Yogyakarta: Rineka Cipta.

Depdiknas. (2003). Undang-undang Republik Indonesia Nomor 20 Tahun 2003 tentang Sistem Pendidikan Nasional. Jakarta: Depdiknas

Hosnan. (2014). Pendekatan Saintifik dan Kontekstual dalam Pembelajaran Abad 21. Bogor: Ghalia Indonesia.

In'am, A \& Hajar, S. (2017). Learning Geometry through Discovery Learning Using a Scientific Approach. International Journal of Instruction, 10 (1), 55-70.

Kuswati, W. (2015). Penggunaan Metode Discovery Dengan Media Realia dalam Peningkatan Pembelajaran IPA di Kelas IV SDN 1 Kedungwinangun Tahun Pelajaran 2014/2015. Kalam Cendekia. 3 (6.1). 639-643.

Munadi, Y. (2013). Media Pembelajaran: Sebuah Pendekatan Baru. Jakarta: Referensi.

Sapriya. (2014). Pendidikan IPS. Bandung: Remaja Rosdakarya.

Susanto, A . (2014). Pengembangan Pembelajaran IPS di Sekolah Dasar. Jakarta: Prenadamedia Group. 